\title{
Estimasi Ragam, Jumlah Kelompok Gen Pengendali Karakter dan Heritabilitas Tomat di Dataran Rendah
}

\author{
Estimation of Variance, Number of Controlling Genes Group and Heritability \\ of Tomato at the Low Altitude
}

\author{
Helfi Eka Saputra ${ }^{1 *}$, Dwi Wahyuni Ganefianti ${ }^{1}$, Umi Salamah ${ }^{1}$, Yenny Sariasih ${ }^{2}$, \\ dan Nico Dwi Ardiansyah ${ }^{3}$
}

Diterima 18 Maret 2018/Disetujui 02 April 2019

\begin{abstract}
Crossing is one technique to expand the genetic diversity. The research objective was to estimate the genetic variability, number of genes controlling characters and heritability tomato yield and yield component in the F2 population crosses TMU-1 xTMU-2 at the low altitude. The research was conducted from April to October 2016 in Kandang Limun, Bengkulu city with a height of $10 \mathrm{~m}$ (low altitude). Estimates of genetic variability, heritability and number of genes controlling the yield character is determined based on the mean and variance in the population. The results showed all of the characters that were tested had a number of genes controlling the character as much as one gene. Characters are controlled by a single gene is expected fixation genes to be rapid in some early cycles of selection. Eight characters had a high heritability. Each character and heritability is flowering day (52.90\%), the number of fruits per plant (92.99\%), fruits length (77.10\%), fruits diameter (71.76\%), the number of locul fruits (85.68\%), thick flesh (73.05\%), total soluble solids (89.77\%) and fruit weight per plant (65.19\%).
\end{abstract}

Keywords: diversity, heritability, low altitude, number of genes group, yield component

\begin{abstract}
ABSTRAK
Persilangan merupakan salah satu teknik untuk memperluas keragaman genetik. Tujuan penelitian adalah untuk mengestimasi keragaman genetik, jumlah kelompok gen pengendali karakter dan heritabilitas hasil dan komponen hasil tomat pada populasi F2 persilangan TMU-1 x TMU-2 di dataran rendah. Penelitian dilaksanakan di Kelurahan Kandang Limun, Kota Bengkulu dengan ketinggian $10 \mathrm{~m}$ dpl (dataran rendah) dari bulan April sampai Oktober 2016. Estimasi keragaman genetik, heritabilitas dan jumlah kelompok gen pengendali karakter ditentukan berdasarkan nilai tengah dan ragam pada populasi. Hasil penelitian menunjukkan semua karakter yang diuji memiliki jumlah kelompok gen pengendali sebanyak satu gen. Karakter yang dikendalikan oleh satu gen diharapkan fiksasi gen-gen akan cepat tercapai pada beberapa siklus awal seleksi. Delapan karakter memiliki heritabilitas tinggi. Masing-masing karakter dan heritabilitasnya adalah umur berbunga (52.90\%), jumlah buah per tanaman (92.99\%), panjang buah (77.10\%), diameter buah $(71.76 \%)$, jumlah rongga buah $(85.68 \%)$, tebal daging buah $(73.05 \%)$, padatan total terlarut $(89.77 \%)$ dan bobot buah per tanaman $(65.19 \%)$.
\end{abstract}

Kata kunci: dataran rendah, heritabilitas, jumlah kelompok gen, keragaman, komponen hasil

\footnotetext{
${ }^{1}$ Program studi Agroekoteknologi, Fakultas Pertanian Universitas Bengkulu,

Jl. W.R. Supratman, Bengkulu 38371A, Indonesia

${ }^{2}$ Program studi Proteksi Tanaman, Fakultas Pertanian Universitas Bengkulu

Jl. W.R. Supratman, Bengkulu 38371A, Indonesia

${ }^{3}$ Alumni Program studi Agroekoteknologi, Fakultas Pertanian Universitas Bengkulu

E-mail : hesaputra@unib.ac.id (*Penulis korespondensi)
} 


\section{PENDAHULUAN}

Selama periode 2010-2014, produksi tomat (Solanum esculentum) mengalami peningkatan yang nyata, yaitu dari 891616 ton tahun $^{-1}$ menjadi 915987 ton tahun ${ }^{-1}$. Luas panen tomat mengalami penurunan dari 61154 ha tahun 2010 menjadi 59008 ha tahun 2014. Peningkatan produksi juga diikuti peningkatan produktivitas dari 14.58 ton $\mathrm{ha}^{-1}$ pada tahun 2010 menjadi 15.52 ton $\mathrm{ha}^{-1}$ pada tahun 2014 (Kementan, 2015). Dalam skala ASEAN, pada tahun 2012 Indonesia merupakan negara yang memiliki sumbangsih terbesar untuk produksi tomat, namun jika diurutkan dengan negaranegara penghasil tomat dunia, Indonesia masih berada di urutan 21 di bawah Cina, USA, India, Nigeria, Mesir, dan negara lainnya. Di samping itu, pada tahun 2013 Indonesia masih tercatat sebagai negara pengimpor tomat dengan nilai impor sebesar 56000 US\$ (Pusdatin, 2014). Berdasarkan hal tersebut kebutuhan tomat baik skala dalam negeri maupun luar negeri sangat besar sehingga peningkatan produksi tetap menjadi skala prioritas.

Peningkatan produksi tomat dapat dilakukan dengan tindakan budidaya yang tepat. Faktor lingkungan tempat tumbuh tomat menjadi perhatian penting agar tanaman tomat dapat tumbuh dengan baik. Lingkungan tumbuh tomat yang terbaik adalah dataran tinggi. Hal ini ditunjukkan dengan jumlah varietas yang banyak dijual merupakan varietas yang beradaptasi dan memiliki kualitas buah yang baik di dataran tinggi. Ke depan penggunaan areal tanam di dataran tinggi juga menimbulkan masalah karena sebagian wilayah dataran tinggi merupakan daerah konservasi dan kompetisi sesama komoditas hortikultura selain tomat sehingga perluasan area tanam tidak bisa banyak diharapkan di dataran tinggi.

Solusi yang bisa dilakukan agar perluasan areal tanam tetap dapat dilakukan adalah dengan perluasan areal tanam tomat ke dataran rendah. Penggunaan dataran rendah menjadi alternatif yang baik karena umumnya dataran rendah bukan areal konservasi dan tidak banyak komoditas hortikultura yang dapat ditanam di dataran rendah karena suhu yang lebih tinggi. Solusi tersebut tidak serta merta dapat dilakukan pada dataran rendah karena lingkungan tumbuh tomat tidak sesuai.
Firon et al. (2006) melaporkan bahwa produksi tomat yang rendah disebabkan ukuran buah yang kecil dan jumlah buah terbentuk sedikit pada kondisi suhu tinggi. Beberapa penelitian menunjukkan belum ada varietas unggul tomat dataran rendah dan apabila varietas-varietas unggul yang ada sekarang ditanam di dataran rendah, maka yang diperoleh produksi yang rendah dan kuliatas buah yang tidak sesuai dengan permintaan konsumen. Permasalahan tersebut dapat diatasi dengan perakitan varietas unggul tomat berdaya hasil tinggi di dataran rendah menjadi satu-satunya solusi yang tepat, efektif, dan efisien untuk mendapatkan produksi tomat yang tinggi.

Salah satu metode dalam kegiatan pemuliaan tanaman adalah persilangan. Tujuan dilakukannya persilangan adalah untuk menyatukan masing-masing karakter unggul yang ada pada macam-macam genotipe dalam satu genotipe. Populasi F2 merupakan populasi bersegregasi maksimal. Oleh sebab itu, estimasi keragaman genetik, heritabilitas, dan jumlah kelompok gen pengendali karakter sangat baik dilakukan pada populasi ini.

Kurniawan (2006) melaporkan bahwa jumlah gen pengendali karakter ukuran buah sebanyak empat gen. Rai et al. (2005) melaporkan bahwa jumlah kelompok gen pengendali karakter bobot per buah sebanyak satu kelompok gen. Hazra dan Ansary (2008) melaporkan bahwa jumlah buah per tanaman dan bobot buah per tanaman juga dikendalikan oleh satu kelompok gen.

Beberapa penelitian tomat sebelumnya menunjukkan bahwa heritabilitas arti luas untuk karakter jumlah buah per tanaman (37.27-96.56\%) dan bobot buah per tanaman memiliki heritabilitas arti luas tergolong sedang hingga tinggi (31.4-97.15\%) (Saeed et al., 2007; Hazra dan Ansary, 2008; Islam et al., 2012). Berdasarkan penelitian Al-Aysh et al. (2012) dan Kumar et al. (2013) bahwa karakter bobot per buah memiliki nilai heritabilitas arti luas berkisar 83.16-87.00\%

Tujuan penelitian adalah untuk mengestimasi keragaman genetik, jumlah kelompok gen pengendali karakter dan heritabilitas hasil dan komponen hasil tomat pada populasi F2 persilangan TMU-1 x TMU2 di dataran rendah. 


\section{BAHAN DAN METODE}

Penelitian dilaksanakan dari bulan April sampai Oktober 2016 di Kelurahan Kandang Limun, Kota Bengkulu dengan ketinggian 10 meter di atas permukaan laut $(\mathrm{m} \mathrm{dpl})$ dataran rendah). Estimasi keragaman genetik, heritabilitas dan jumlah kelompok gen pengendali karakter ditentukan berdasarkan nilai tengah dan ragam pada populasi. Setiap populasi meliputi tetua $1(\mathrm{P} 1)$, tetua 2 (P2) dan populasi segregasi (F2). Tetua $1(\mathrm{P} 1)$ memiliki ciri-ciri umur berbunga genjah dan jumlah rongga buah lebih dari 3 rongga, sedangkan tetua 2 (P2) memiliki ciri-ciri umur berbunga lama dan jumlah rongga buah 2 rongga. Masing-masing tetua (P1 dan P2) ditanam sebanyak 20 tanaman, sedangkan populasi segregasi (F2) ditanam sebanyak 200 tanaman. Pengamatan pada tetua dilakukan hanya 10 tanaman, sedangkan untuk populasi segregasi (F2) pengamatan dilakukan pada semua tanaman (tidak ada tanaman contoh). Masingmasing tanaman tomat ditanam dengan jarak tanam $50 \mathrm{~cm} \times 50 \mathrm{~cm}$ pada petak berukuran $5 \mathrm{~m}$ $\mathrm{x} 1 \mathrm{~m}$. Pembibitan dilakukan selama 4 minggu. Pemupukan NPK (16:16:16) dilakukan satu minggu sekali dengan konsentrasi $10 \mathrm{~g} \mathrm{~L}^{-1}$ sebanyak $250 \mathrm{~mL} \tan ^{-1}$. Pengendalian organisme pengganggu tanaman dilakukan dua minggu sekali dengan menggunakan fungisida berbahan aktif Mancozeb $80 \%$ dengan konsentrasi $2 \mathrm{~g} \mathrm{~L}^{-1}$ dan insektisida berbahan aktif Profenofos $500 \mathrm{~g} \mathrm{~L}^{-1}$ dengan konsentrasi 2 $\mathrm{mL} \mathrm{L}^{-1}$. Pengendalian gulma dilakukan secara manual. Pemanenan dilakukan jika buah sudah berwarna kuning kemerah-merahan dan dilakukan dua kali seminggu selama enam minggu.

Komponen ragam dan heritabilitas dapat diduga sebagai berikut (Roy, 2000):

Ragam lingkungan $\left(\mathrm{S}^{2}\right)=\frac{\mathrm{S}_{\mathrm{P} 1}^{2}+\mathrm{S}_{\mathrm{P} 2}^{2}}{2}$

Ragam fenotipe $\left(\mathrm{S}^{2} \mathrm{P}\right)=\mathrm{S}_{\mathrm{F} 2}^{2}$

Ragam genotipe $\left(\mathrm{S}_{\mathrm{G}}{ }_{\mathrm{G}}\right)=\mathrm{S}_{\mathrm{F} 2}^{2}-\left(\frac{\mathrm{S}_{\mathrm{P} 1}+\mathrm{S}_{\mathrm{P} 2}^{2}}{2}\right)$

Heritabilitas arti luas $\left(\mathrm{h}^{2}{ }_{\mathrm{bs}}\right)=\frac{\mathrm{S}_{\mathrm{F} 2}^{2}-\left(\frac{\mathrm{S}_{\mathrm{P} 1}^{2}+\mathrm{S}_{\mathrm{P} 2}^{2}}{2}\right)}{\mathrm{S}_{\mathrm{F} 2}^{2}}$

Keterangan:

$\mathrm{S}^{2}{ }_{\mathrm{P}_{1}}=$ ragam tetua 1 ,

$\mathrm{S}_{\mathrm{P}_{2}}^{2}=$ ragam tetua 2 dan

$\mathrm{S}_{\mathrm{F}_{2}}^{2}=$ ragam populasi $\mathrm{F} 2$.
Jumlah kelompok gen pengendali karakter dapat diduga dari nilai tengah dan komponen ragam (Gusmini et al., 2007). Menurut Roy (2000) jumlah faktor efektif (kelompok gen pengendali) dihitung berdasarkan nilai tengah dan ragam yaitu: Jumlah kelompok gen pengendalian karakter (Metode Falconer)

$$
=\frac{\left(\mu_{\mathrm{P} 1}-\mu_{\mathrm{P} 2}\right)^{2}}{8\left(\mathrm{~S}_{\mathrm{F}_{2}}^{2}-\mathrm{S}_{\mathrm{E}}^{2}\right)}
$$

Keterangan:

$\mu_{\mathrm{P} 1}=$ nilai tengah tetua 1 ,

$\mu_{\mathrm{p} 2}=$ nilai tengah tetua 2 ,

$\mathrm{S}_{\mathrm{F}_{2}}^{2_{2}}=$ ragam populasi $\mathrm{F} 2$, dan

$\mathrm{S}_{\mathrm{E}}^{2}=$ ragam lingkungan.

Karakter yang diamati adalah umur berbunga (hst), jumlah buah per tanaman (buah), panjang buah $(\mathrm{cm})$, diameter buah $(\mathrm{cm})$, jumlah rongga buah (rongga), tebal daging buah $(\mathrm{cm})$, kekerasan buah $\left(\mathrm{kg} \mathrm{cm}^{-1}\right)$, padatan total terlarut ( ${ }^{\circ}$ brik), bobot per buah (g) dan bobot buah per tanaman (g).

\section{HASIL DAN PEMBAHASAN}

Informasi tentang jumlah kelompok gen pengendali diperlukan untuk salah satu pertimbangan dalam kegiatan seleksi. Jika suatu karakter dikendalikan oleh satu kelompok gen maka fiksasi gen-gen yang diharapkan akan cepat tercapai pada beberapa siklus awal seleksi, dibandingkan apabila suatu karakter dikendalikan oleh banyak kelompok gen. Jumlah kelompok gen pengendali pada setiap karakter disajikan pada Tabel 1. Semua karakter yang diuji memiliki jumlah kelompok gen pengendali sama dengan satu kelompok.

Akhtar dan Hazra (2013) melaporkan bahwa jumlah kelompok gen pengendali pada karakter padatan total terlarut adalah satu gen. Zdravkovic et al. (2011) melaporkan bahwa adanya pengaruh epistasis pada karakter jumlah buah per tandan sehingga menunjukkan pada karakter tersebut dikendalikan oleh lebih dari satu gen. Murti et al. (2004) melaporkan karakter panjang dan diameter buah dikendalikan secara poligen (banyak gen), sedangkan jumlah rongga buah dikendalikan oleh dua gen. Masruroh et al. (2009) melaporkan bahwa panjang buah, diameter buah dan jumlah rongga buah 
dikendalikan oleh dua gen. Pada penelitian ini terdapat perbedaan dengan penelitian Murti et al. (2004) dan Masruroh et al. (2009), khususnya pada karakter panjang buah, diameter buah dan jumlah rongga buah karena pada penelitian ini diperoleh jumlah gen sebanyak satu kelompok gen. Perbedaan jumlah gen antara penelitian ini dengan penelitian sebelumnya dikarenakan kombinasi persilangan yang digunakan berbeda sehingga dasar genetiknya juga berbeda-beda.

Pada penelitian ini terdapat jumlah kelompok gen pengendali karakter yang bernilai negatif yaitu karakter kekerasan buah. Hal yang sama juga telah dilaporkan oleh Syukur et al. (2010) dan Saputra (2014) bahwa terdapat karakter yang memiliki hasil perhitungan jumlah gen yang negatif, selanjutnya untuk karakter yang memiliki nilai negatif menunjukkan karakter tersebut dikendalikan oleh satu gen.
Estimasi heritabilitas digunakan untuk mengetahui seberapa besar peran genetik dalam mempengaruhi keragaman yang terbentuk. Pada penelitian ini diperoleh heritabilitas berkisar 0-92.99\% (Tabel 2). Semakin tinggi nilai heritabilitas menunjukkan semakin besar peran genetik dalam membentuk keragaman. Nilai heritabilitas diperlukan untuk kegiatan seleksi karena dalam kegiatan seleksi dibutuhkan karakter yang diwariskan ke generasi selanjutnya. Suatu tampilan terbaik pada setiap karakter dapat diwariskan ke generasi selanjutnya apabila tampilan tersebut disebabkan peran genetik. Sebaliknya jika tampilan terbaik tersebut disebabkan oleh peran lingkungan maka tampilan terbaik tersebut tidak akan diperoleh di generasi selanjutnya (penanaman selanjutnya). Oleh sebab itu, peran genetik yang besar diperlukan untuk kegiatan seleksi. Peran genetik yang besar dapat diduga dari nilai heritabilitas yang tinggi.

Tabel 1. Jumlah kelompok gen pengendali pada setiap karakter

\begin{tabular}{|c|c|c|c|c|c|c|c|c|}
\hline Karakter & $\begin{array}{l}\text { Rentang } \\
\text { Tetua } 1 \\
\text { (P1) }\end{array}$ & $\mu_{\mathrm{P} 1}$ & $\begin{array}{l}\text { Rentang } \\
\text { Tetua } 2 \\
\text { (P2) }\end{array}$ & $\mu_{\mathrm{p} 2}$ & $\begin{array}{c}\text { Rentang } \\
\text { F2 }\end{array}$ & $\mathrm{S}_{\mathrm{F}_{2}}^{2}$ & $\mathrm{~S}_{\mathrm{E}}^{2}$ & $\begin{array}{c}\text { Jumlah } \\
\text { Kelompok } \\
\text { Gen } \\
\text { Pengendali } \\
\text { Karakter }\end{array}$ \\
\hline $\begin{array}{l}\text { Umur } \\
\text { Berbunga } \\
\text { Jumlah }\end{array}$ & $21.00-30.00$ & 27.20 & $32.00-41.00$ & 37.40 & $21.00-53.00$ & 39.81 & 18.75 & $0.62[1]$ \\
\hline $\begin{array}{l}\text { Buah Per } \\
\text { Tanaman }\end{array}$ & $11.00-18.00$ & 14.00 & $11.00-20.00$ & 15.60 & $3.00-77.00$ & 169.82 & 11.90 & $0.002[1]$ \\
\hline $\begin{array}{l}\text { Panjang } \\
\text { Buah }\end{array}$ & $3.38-4.24$ & 3.76 & $3.44-4.36$ & 3.72 & $1.23-4.98$ & 0.71 & 0.16 & $0.001[1]$ \\
\hline $\begin{array}{l}\text { Diameter } \\
\text { Buah }\end{array}$ & $3.22-4.44$ & 3.83 & $2.80-3.64$ & 3.29 & $1.10-4.30$ & 0.63 & 0.18 & $0.08[1]$ \\
\hline $\begin{array}{l}\text { Jumlah } \\
\text { Rongga } \\
\text { Buah } \\
\text { Tebal }\end{array}$ & $3.60-5.00$ & 4.64 & $2.00-2.00$ & 2.00 & $2.00-6.00$ & 1.28 & 0.18 & $0.79[1]$ \\
\hline $\begin{array}{l}\text { Daging } \\
\text { Buah }\end{array}$ & $0.48-0.58$ & 0.52 & $0.34-0.64$ & 0.43 & $0.10-1.00$ & 0.03 & 0.01 & $0.05[1]$ \\
\hline $\begin{array}{l}\text { Kekerasan } \\
\text { Buah } \\
\text { Padatan }\end{array}$ & $1.20-1.56$ & 1.35 & $1.38-2.02$ & 1.63 & $1.00-1.66$ & 0.02 & 0.04 & $-0.48[1]$ \\
\hline $\begin{array}{l}\text { Total } \\
\text { Terlarut }\end{array}$ & $4.20-5.00$ & 4.76 & $4.00-4.80$ & 4.48 & $2.67-6.20$ & 1.27 & 0.13 & $0.01[1]$ \\
\hline $\begin{array}{l}\text { Bobot Per } \\
\text { Buah }\end{array}$ & $22.74-51.09$ & 33.98 & $16.29-35.19$ & 24.29 & $3.78-44.65$ & 109.31 & 94.31 & $0.78[1]$ \\
\hline $\begin{array}{l}\text { Bobot Buah } \\
\text { Per } \\
\text { Tanaman }\end{array}$ & $153.90-637.40$ & 417.72 & $208.00-423.50$ & 300.23 & $34.50-1332.40$ & 75438.70 & 26259.70 & $0.03[1]$ \\
\hline
\end{tabular}


Beberapa penelitian tomat sebelumnya menunjukkan bahwa heritabilitas arti luas untuk karakter jumlah buah per tanaman dan bobot buah per tanaman memiliki heritabilitas arti luas tergolong sedang hingga tinggi dengan nilai masing-masing 37.27-96.56\% dan 31.4-97.15\% (Saeed et al., 2007; Hazra dan Ansary, 2008; Islam et al., 2012; Saputra et al., 2014). Heritabilitas karakter panjang buah tergolong rendah sampai tinggi dengan nilai duga sebesar $96.15 \%$ (Hermanto et al., 2017), 97.60\% (Saputra, 2014), 78.10\% (Reddy et al., 2013), $19.45 \%$ (Islam et al., 2012) dan $99.40 \%$ (Kaushik et al., 2011). Heritabilitas karakter diameter buah tergolong sedang sampai tinggi dengan nilai duga sebesar $96.60 \%$ (Saputra, 2014), 43.10\% (Reddy et al., 2013), 86.84\% (Islam et al., 2012) dan 98.00\% (Kaushik et al., 2011). Heritabilitas karakter padatan total terlarut tergolong sedang hingga tinggi dengan nilai duga berkisar 20.38\% - 90.37\% (Islam et al., 2012; Akhtar dan Hazra, 2013; Reddy et al., 2013; Saputra, 2014). Saputra 2014 melaporkan heritabilitas tebal daging buah dan jumlah rongga buah masing-masing sebesar $91.10 \%$ dan $93.00 \%$. Berdasarkan kriteria Roy (2000), terdapat 8 karakter yang memiliki heritabilitas tinggi. Masing-masing karakter dan heritabilitasnya adalah umur berbunga $(52.90 \%)$, jumlah buah per tanaman $(92.99 \%)$, panjang buah $(77.10 \%)$, diameter buah (71.76\%), jumlah rongga buah (85.68\%), tebal daging buah (73.05\%), padatan total terlarut $(89.77 \%)$ dan bobot buah per tanaman $(65.19 \%)$. Karakter yang memiliki nilai heritabilitas tinggi menunjukkan peran genetik lebih banyak dibandingkan peran lingkungan dalam membentuk keragaman pada karakter tersebut. Heritabilitas yang tinggi disebabkan dengan keragaman yang tinggi pada populasi F2 dan juga nilai rentang yang besar antar individu pada populasi F2 (Tabel 1).

Dua karakter lain yaitu kekerasan buah dan bobot per buah memiliki heritabilitas rendah yaitu masing-masing $0 \%$ dan $13.72 \%$. Karakter yang memiliki nilai heritabilitas rendah menunjukkan peran lingkungan lebih banyak dibandingkan peran genetik dalam membentuk keragaman pada karakter tersebut. Berbeda halnya dengan penelitian Al-Aysh et al. (2012) dan Kumar et al. (2013) bahwa karakter bobot per buah memiliki nilai heritabilitas arti luas tinggi yaitu berkisar 83.16-87.00\%. Berdasarkan penelitian Reddy et al. (2013) bahwa karakter bobot per buah $90.90 \%$. Nilai heritabilitas yang berbeda pada karakter yang diamati dikarenakan latar belakang genetik berbeda (populasi tetua yang berbeda).

Tabel 2. Komponen ragam dan heritabilitas setiap karakter

\begin{tabular}{lrrrrc}
\hline \multicolumn{1}{c}{ Karakter } & \multicolumn{1}{c}{$\mathrm{S}_{\mathrm{E}}^{2}$} & \multicolumn{1}{c}{$\mathrm{S}_{\mathrm{P}}^{2}$} & \multicolumn{1}{c}{$\mathrm{S}_{\mathrm{G}}^{2}$} & \multicolumn{1}{c}{$\mathrm{h}_{\mathrm{bs}}^{2}$} & Keterangan \\
\hline Umur Berbunga & 18.75 & 39.81 & 21.06 & 52.90 & Tinggi \\
Jumlah Buah Per Tanaman & 11.90 & 169.82 & 157.92 & 92.99 & Tinggi \\
Panjang Buah & 0.16 & 0.71 & 0.55 & 77.10 & Tinggi \\
Diameter Buah & 0.18 & 0.63 & 0.45 & 71.76 & Tinggi \\
Jumlah Rongga Buah & 0.18 & 1.28 & 1.10 & 85.68 & Tinggi \\
Tebal Daging Buah & 0.01 & 0.03 & 0.02 & 73.05 & Tinggi \\
Kekerasan Buah & 0.04 & 0.02 & 0 & 0 & Rendah \\
Padatan Total Terlarut & 0.13 & 1.27 & 1.14 & 89.77 & Tinggi \\
Bobot Per Buah & 94.31 & 109.31 & 15.00 & 13.72 & Rendah \\
Bobot Buah Per Tanaman & 26259.67 & 75438.69 & 49179.02 & 65.19 & Tinggi \\
\hline Ketrang
\end{tabular}

Keterangan: $\mathrm{S}^{2} \mathrm{E}=$ ragam lingkungan, $\mathrm{S}^{2} \mathrm{P}=$ ragam fenotipe, $\mathrm{S}^{2}{ }_{\mathrm{G}}=$ ragam genotipe, $\mathrm{h}^{2} \mathrm{bs}=$ heritabilitas 


\section{KESIMPULAN}

Semua karakter yang diuji memiliki jumlah kelompok gen pengendali sebanyak satu kelompok gen. Delapan karakter memiliki heritabilitas tinggi yaitu umur berbunga (52.90\%), jumlah buah per tanaman $(92.99 \%)$, panjang buah $(77.10 \%)$, diameter buah (71.76\%), jumlah rongga buah $(85.68 \%)$, tebal daging buah $(73.05 \%)$, padatan total terlarut $(89.77 \%)$ dan bobot buah per tanaman (65.19\%). Dua karakter memiliki heritabilitas rendah yaitu kekerasan buah $(0 \%)$ dan bobot per buah (13.72\%).

\section{UCAPAN TERIMA KASIH}

Terima kasih disampaikan kepada Universitas Bengkulu yang sudah mendanai penelitian ini melalui PNBP TA 2016 serta semua pihak yang telah membantu.

\section{DAFTAR PUSTAKA}

Akhtar, S., P. Hazra. 2013. Nature of gene action for fruit quality characters of tomato (Solanum lycopersicum). Afr. J. Biotechnol. 12(20): 2869-2875.

Al-Aysh, F., M.M. Al-Serhan, A. Al-Shareef, M. Al-Nasser, H. Kutma. 2012. Study of genetic parameters and character interrelationship of yield and some yield component in tomato (Solanum lycopersicum L.). Intl. J. Genet. 2(2): 29-33.

Firon, N., R. Shaked, M.M. Peet, D.M. Pharr, E. Zamski, K. Rosenfeld, L. Althan, E. Pressman. 2006. Pollen grains of heat tolerant tomato cultivars retain higher carbohydrate concentration under heat stress conditions. Sci. Hortic. 109: 212217.

Gusmini, G., T.C. Wehner, A.B. Donaghy. 2007. SASQuant: A SAS software program to estimate genetic effects and heritabilities of quantitative traits in populations consisting of 6 related generations. Journal of Heredity. 98(4): 345-350.
Hazra, P., S.H. Ansary. 2008. Genetics of heat tolerance for floral and fruit set to high temperature stress in tomato (Lycopersicon esculentum Mill.). SABRAO J. Breed. Genet. 40(2): 117125.

Hermanto, R., M. Syukur, Widodo. 2017. Pendugaan ragam genetik dan heritabilitas karakter hasil dan komponen hasil tomat (Lycopersicum esculentum Mill.) di dua lokasi. J. Hort. Indonesia. 8(1): 31-38.

Islam, M.S., H.C. Mohanta, M.R. Ismail, M.Y. Rafii, M.A. Malek. 2012. Genetic variability and trait relationship in cherry tomato (Solanum lycopersicum L. var cerasiforme (dunnal) a gray. Bangladesh J. Bot. 41(2): 163-167.

[KEMENTAN] Kementerian Pertanian. 2015. Data Produksi, Produktivitas, Ekspor Dan Impor Tomat. Jakarta: Kementrian Pertanian Republik Indonesia.

Kaushik, S.K., D.S. Tomar, A.K. Dixit. 2011. Genetics of fruit yield and it's contributing character in tomato (Solanum lycopersicum). J. Agric. Biotech. Sustainable Dev. 3(10): 209213.

Kumar, V., R. Nandan, K. Srivastava, S.K. Sharma, R. Kumar, A. Kumar. 2013. Genetic parameters and correlations study for yield and quality traits in tomato (Solanum lycopersicum L.). Plant Archives. 13(1): 463-467.

Masruroh, F.M., Nasrullah, R.H. Murti. 2009. Analisis rata-rata generasi hasil persilangan tomat LV 6123 dan LV 5152. Agrivita. 31(2): 166-177.

Murti, R.H., T. Kurniawati, Nasrullah. 2004. Pola pewarisan karakter buah tomat. Zuriat. 15(2): 140-149.

Pusat Data dan Sistem Informasi Pertanian. 2014. Outlook Komoditi Tomat. Kementrian Pertanian Republik Indonesia. Jakarta. 
Rai, M., A.K. Singh, R.S. Pan, V.S.R.K. Prasad. 2005. Genetic analysis of yield and its components in tomato. Veg. Sci. 32(2): $177-178$

Reddy, B.R., D.S. Reddy, K. Reddaiah, N. Sunil. 2013. Study on genetic variability, heritability and genetic advance for yield and quality traits in tomato (Solanum lycopersicum L.). Int. J. Curr. Microbiol. App. Sci. 2(9): 238244.

Roy, D. 2000. Plant Breeding, Analysis and Exploitation of Variation. Narosa Publishing House. New Delhi.

Saeed, A., K. Hayat, A.L. Khan, S. Iqbal, G. Abbas. 2007. Assessment of genetic variability and heritability in Lycopersicon esculentum Mill. Int. J. Agri. Biol. 9(2): 375-377.

Saputra, H.E. 2014. Pewarisan Karakter Kuantitatif Tomat (Lycopersicon esculentum Mill.) untuk Dataran Rendah. Tesis. Sekolah Pascasarjana Institut Pertanian Bogor. Bogor. 90 hal.

Saputra, H.E., M. Syukur, S.I. Aisyah. 2014. Pendugaan daya gabung dan heritabilitas komponen hasil tomat pada persilangan dialel penuh. J. Agron. Indonesia. 42(3): 203-209.

Syukur, M., S. Sujiprihati, R. Yunianti, Undang. 2010. Diallel analysis using hayman method to study genetic parameters of yield components in pepper (Capsicum annuum L.). Hayati J. Biosci. 17(4): 183-188.

Zdravkovic, J., N. Pavlovi, Z. Girek, M. Brdar-Jokanovic, D. Savic, M. Zdravkovic, D. Cvikic. 2011. Generation mean analysis of yield components and yield in tomato (Lycopersicon esculentum Mill.). Pak. J. Bot. 43(3): 1575-1580. 